\title{
Health crisis and slowdown in the process of opening facilities for adults with disabilities
}

Cross-views during the first lockdown in two French departments

(Lozère and Seine-et-Marne)

Elise Martin and Noémie Rapegno

\section{OpenEdition}

\section{Journals}

Electronic version

URL: https://journals.openedition.org/rfst/1622

DOI: $10.4000 /$ rfst. 1622

ISSN: 2492-3672

This article is a translation of:

Crise sanitaire et ralentissement du processus d'ouverture vers l'extérieur d'établissements pour adultes handicapés - URL : https://journals.openedition.org/rfst/1577 [fr]

Publisher

Espaces et SOciétés (UMR 6590)

\section{Electronic reference}

Elise Martin and Noémie Rapegno, "Health crisis and slowdown in the process of opening facilities for adults with disabilities", Revue francophone sur la santé et les territoires [Online], Pandemic, crises and perspectives: territorial readings of Covid-19, Online since 20 January 2022, connection on 29 January 2022. URL: http://journals.openedition.org/rfst/1622 ; DOI: https://doi.org/10.4000/rfst.1622

This text was automatically generated on 29 January 2022

\section{c) (1) (ㅇ)}

La Revue francophone sur la santé et les territoires est mise à disposition selon les termes de la Licence Creative Commons Attribution - Pas d'Utilisation Commerciale - Partage dans les Mêmes Conditions 4.0 International. 


\title{
Health crisis and slowdown in the process of opening facilities for adults with disabilities
}

\author{
Cross-views during the first lockdown in two French departments \\ (Lozère and Seine-et-Marne)
}

Elise Martin and Noémie Rapegno

1 The article examines how the first French lockdown has been perceived in residential care institutions for adults with disabilities, one located in the Paris region and the other in Lozère, a rural area in the south of France. The article is based on the one hand on interviews of professionals of the care institutions (educators, caregivers, directors) and of one resident of the Northern one before, during and after the first lockdown, and on the other hand on the analysis of sanitary protocols implemented in the two structures (roadmaps for professionals, steps to be followed) which are a transcript of the ARS (regional health agency) recommendations.

2 The survey shows that the health crisis and lockdown have slowed down the processes of inclusion of people with disabilities and all actions aiming at their integration, since sanitary measures have taken precedence over the other accompaniment missions (like social support). The two structures have been closed and cut off from the outside, which has resulted in the suspension of paramedical interventions and family visits. The atmosphere and spatial organisation of the institutions have been transformed as well. Spaces have been sanitized (disinfection, sterilisation, particular attention to hygiene) and covid areas have been created to isolate the suspected cases of Covid-19. This has shrunk residents' living space. To this must be added the fact that people were quarantined within the institutions too. In the Southern one, some residents were isolated in their unit and a few people (16) were even isolated in their individual bedrooms. In the Northern institution, people were put into isolation in their studio flat for several months.

3 In the context of closing up and narrowing the living space, and curtailing individual liberties, the article demonstrates that professionals have tried to maintain something 
of a "normal life". The shielding measures were adapted to residents, who had to wear a mask only if it was bearable for them. Outside activities have been adjusted too. The rural area of the Lozère institution has made it possible for people to go out for a walk every day. In contrast, the Paris region institution being in a more densely populated suburban area, going out was only proposed to people who could not handle the lockdown.

Furthermore, professionals have adapted by offering individualized care and trying to preserve collective dynamics. In Lozère, some activities have been organized in each unit, like manual activities. In the Paris region, a logbook has been kept and video clips have been regularly posted on social media. Lastly, professionals have tried their best to maintain links with the outside, particularly with close relatives and families. Investing in tablet computers and using electronic messaging have allowed people to not be completely isolated from the rest of the population. In Lozère, a rural area, this link was more difficult to keep up due to a poor internet network.

Finally, the residential care institutions for people with disabilities were confronted with the same dilemma as the residential care institutions for the elderly, namely how to protect without locking and cloistering people up? The first lockdown has narrowed people's living space and freedoms, notably the possibility of giving their point of view. People have not been consulted during the first lockdown, when they actually were the first ones affected. In spite of this, the teams have done everything they could to make the situation more bearable by implanting an "ethic of situation" (Hennion \& VidalNaquet, 2015). The first lockdown has revealed the hybrid identity of care institutions, which shape in-between spaces-neither fully closed, nor fully opened on the outside.

Figure : Timeline

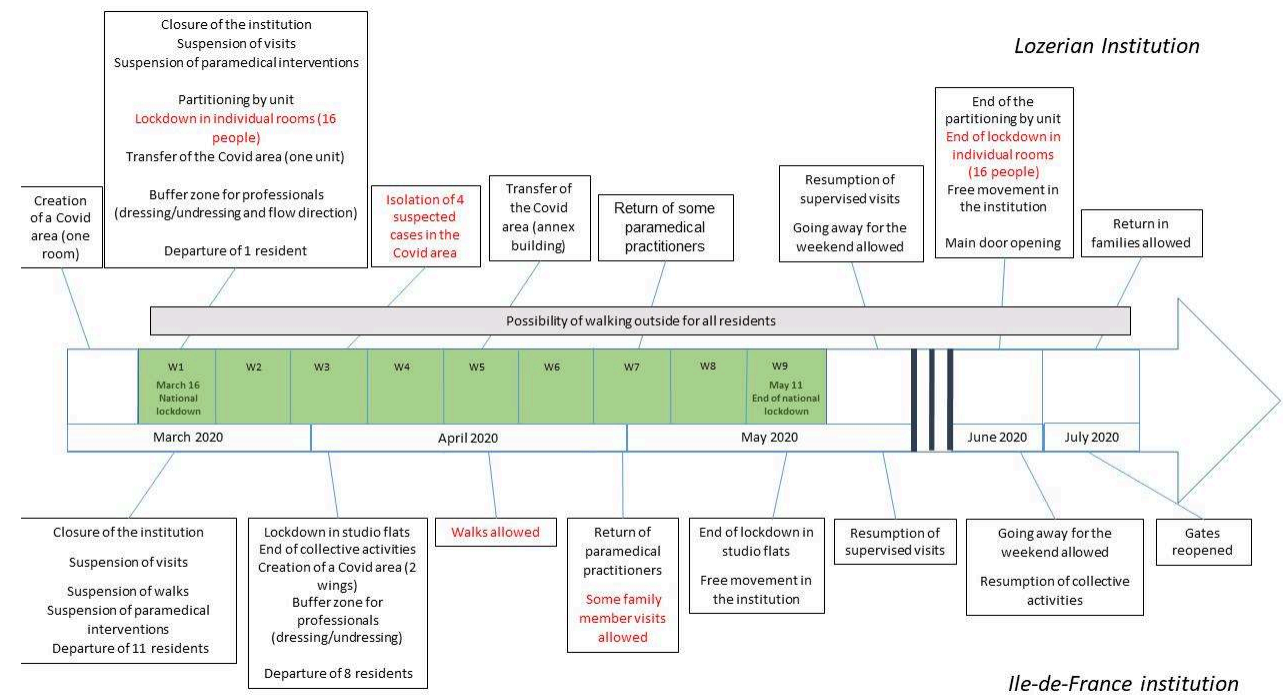

6 Above the timeline are indicated the sanitary measures taken in the Lozère institution. Below the timeline are indicated those taken in the Ile-de-France institution. The arrow spans from March to July 2020, with the green area representing the first national lockdown, divided into weeks (W1, W2...), with its beginning and ending dates. The three black lines indicate a chronological rupture. The measures in red only affected a small number of people, and did not apply to all residents. 
INDEX

Keywords: disability, residential care institutions, inclusion, Covid-19, lockdown, closure, protection 